\title{
Analisis Faktor Risiko Kejadian Berat Badan Lahir Rendah (BBLR) Di Wilayah Kerja UPTD Puskesmas Panga Tahun 2017
}

\author{
Analysis of Low Birth Weight Scheme Factors in The Working Areas UPTD \\ Puskesmas in 2017
}

\author{
Faradilla Safitri*1 $^{\text {, Lia Lajuna }}{ }^{2}$, Asmaul Husna ${ }^{3}$ \\ ${ }^{1,2,3}$ Program Studi D-IV Bidan Pendidik, Fakultas Ilmu Kesehatan, Universitas Ubudiyah Indonesia, Banda Aceh, Indonesia \\ *Korespondensi Penulis: faradilla@uui.ac.id
}

\begin{abstract}
Abstrak
Berat Badan Lahir Rendah (BBLR) menjadi penyebab ke-dua kematian bayi di Aceh yang meningkat setiap tahunnya. Data dari Puskesmas Panga, tahun 2015 bayi dengan berat badan lahir rendah sebanyak 7 bayi, tahun 2016 sebanyak 8 bayi (5.2\%) dan tahun 2017 dari bulan Januari sampai Juli sebanyak 11 bayi (11.7\%).Tujuan dari penelitian ini untuk menganalisis faktor-faktor yang berhubungan dengan kejadian berat badan lahir rendah di wilayah kerja UPTD Puskesmas Panga tahun 2017 . Jenis penelitian analitik dengan pendekatan crosssectional. Populasinya seluruh ibu telah melahirkan bayi bulan Januari - Juli 2017 sebanyak 94 orang, pengambilan sampel dengan cara total populasi. Pengumpulan data tanggal $21 \mathrm{~s} / \mathrm{d}$ 29 Juli 2017. Instrument penelitian menggunakan kuesioner, buku laporan dan buku KIA. Analisis data menggunakan univariat dan bivariat. Hasil analisis bivariat didapat umur $(\mathrm{p}=0.007)$, status gizi $(\mathrm{p}=0.004)$, status ekonomi $(\mathrm{p}=0.521)$, penyakit/komplikasi selama kehamilan $(\mathrm{p}=0.000)$.Kesimpulan hasil penelitian ini ada hubungan umur, status gizi dan penyakit/komplikasi selama kehamilan dengan kejadian berat badan lahir rendah sedangkan tidak ada hubungan status ekomoni dengan kejadian berat badan lahir rendah di Wilayah Kerja UPTD Puskesmas Panga Tahun 2017.
\end{abstract}

Kata kunci : Berat Badan Lahir Rendah, umur, status gizi, penyakit selama hamil

\begin{abstract}
Low Birth Weight (LBW) is the second leading cause of infant mortality in Aceh, which increases annually. Data from Puskesmas Panga, 2015 infants with low birth weight as many as 7 babies, in 2016 as many as 8 babies (5.2\%) and in 2017 from January to July were 11 infants (11.7\%).The purpose of this study was to analyze the factors with low birth weight occurrence in the working area of UPTD Puskesmas Panga in 2017. Types of analytical research with cross-sectional approach. The population of all mothers has given birth to infants in January - July 2017 as many as 94 people, sampling by way of total population. Data collection dated $21 \mathrm{~s} / \mathrm{d} 29$ July 2017. The research instrument used questionnaires, report books and KIA books. Data analysis using univariate and bivariate. Results of bivariate analysis obtained age $(p=0.007)$, nutritional status $(p=0.004)$, economic status $(p$ $=0.521)$, disease / complication during pregnancy $(p=0.000)$. The conclusion of this study is the correlation between age, nutritional status and illness / complication during pregnancy
\end{abstract}


with low birth weight incidence while there is no relation between economic status and low birth weight incidence in the Work Area of UPTD Puskesmas Panga Year 2017.

keywords : LBW, Age, nutrition status, illness during pregnancy

\section{PENDAHULUAN}

Upaya pemeliharaan kesehatan anak ditujukan untuk mempersiapkan generasi yang akan datang yang sehat, cerdas, dan berkualitas serta untuk menurunkan angka kematian anak. Upaya pemeliharaan kesehatan anak dilakukan sejak janin masih dalam kandungan, dilahirkan, setelah dilahirkan, dan sampai berusia delapan belas tahun. Perhatian terhadap upaya penurunan angka kematian neonatal (0-28 hari) menjadi penting karena kematian neonatal memberi kontribusi terhadap 59\% kematian bayi (Kemenkes, 2015).

Berdasarkan hasil Survei Demografi dan Kesehatan Indonesia (SDKI) tahun 2012, angka Kematian Neonatus (AKN) pada tahun 2012 sebesar 19 per 1.000 kelahiran hidup. Angka ini sama dengan AKN berdasarkan SDKI tahun 2007 dan hanya menurun 1 poin dibanding SDKI tahun 2002-2003yaitu 20 per 1.000 kelahiran hidup. Komplikasi yang menjadi penyebab kematian terbanyak yaitu asfiksia, bayi berat lahir rendah, dan infeksi (Riskesdas, 2007).

Secara umum cakupan Angka Kematian Bayi (AKB) di enam tahun terakhir cenderung mengalami penurunan. Tahun 2014 AKB 15/1.000 LH sedangkan tahun 2015 sebesar 12 per 1.000 kelahiran hidup. Beberapa penyebab kematian bayi di Aceh, diantaranya adalah penyakit asfiksia (25\%), BBLR (21\%), gangguan kelainan saluran pernafasan (11\%), kelainan cacat kongenital (10\%), serta penyakit lainnya (6\%). Berat badan Lahir Rendah (BBLR) menjadi penyebab ke-dua kematian bayi di Aceh (Dinkes.Prov Aceh, 2015).

Berat Badan Lahir Rendah (BBLR) adalah bayi yang lahir dengan berat lahir kurang 2.500 gram tanpa memandang masa kehamilan (Prawirohardjo, 2008). Berat Badan Lahir Rendah adalah bayi dengan berat badan lahir kurang dari 2500 gram tanpa memandang usia gestasi yang ditimbang dalam 1 jam setelah lahir (Manuaba, 2007).

Berdasarkan data dari Dinas Kesehatan Provinsi Aceh, kelahiran bayi dengan berat lahir rendah setiap tahunnya meningkat, yaitu pada tahun 2013 sebesar 0.8\%, tahun 2014 sebesar 1.1\% dan tahun 2015 sebesar 1.356 bayi (1.5\%). Data dari Puskesmas Panga, pada tahun 2015 bayi lahir dengan berat badan rendah sebanyak 7 orang, tahun 2016 jumlah kelahiran sebanyak 153 bayi dengan 8 bayi (5.2\%) bayi lahir berat badan rendah dan pada 
tahun 2017 dari bulan Januari sampai Juli, jumlah kelahiran sebanyak 94 orang, dan yang lahir dengan berat badan lahir rendah sebanyak 11 bayi (11.7\%). Terjadi peningkatan jumlah kelahiran bayi dengan berat badan lahir rendah. Dengan demikian, peneliti tertarik ingin menganalisis faktor risiko kejadian berat badan lahir rendah di wilayah kerja UPTD Puskesmas Panga Tahun 2017.

\section{METODE PENELITIAN}

Penelitian ini menggunakan jenis penelitian yang bersifat analitikdengan desain crosssectional. Populasi dalam penelitian ini adalah seluruh ibu yang telah melahirkan bayi di wilayah kerja UPTD Puskesmas Panga dari bulan Januari - Juli s017 yaitu sebanyak 94 orang. Pengambilan sampel dalam penelitian ini ada total populasi. Instrumen penelitian menggunakan kuesioner, buku laporan puskesmas dan buku KIA dan dengan cara wawancara. Pengumpulan data telah dilaksanakan pada tanggal 21 Juli sampai 29 Juli 2017 di Wilayah Kerja UPTD Puskesmas Panga.

\section{HASIL DAN PEMBAHASAN}

Tabel 1. Hubungan Umur Ibu, Status Gizi, Status Ekonomi dan Penyakit/Komplikasi Selama kehamilan dengan kejadian Berat Badan Lahir Rendah di Wilayah Kerja Puskesmas UPTD Puskesmas Panga Tahun 2017

\begin{tabular}{|c|c|c|c|c|c|c|c|}
\hline \multirow{3}{*}{ Variabel } & \multicolumn{4}{|c|}{$\begin{array}{c}\text { Kejadian Berat Badan Lahir } \\
\text { Rendah }\end{array}$} & \multirow{2}{*}{\multicolumn{2}{|c|}{ Jumlah }} & \multirow{3}{*}{$\begin{array}{c}\mathbf{P} \\
\text { Value }\end{array}$} \\
\hline & \multicolumn{2}{|c|}{ BBLR } & \multicolumn{2}{|c|}{ Tidak BBLR } & & & \\
\hline & f & $\%$ & f & $\%$ & $\mathbf{n}$ & $\%$ & \\
\hline \multicolumn{8}{|l|}{ Umur Ibu } \\
\hline a. Berisiko & 5 & 38.5 & 8 & 61.5 & 13 & 100.0 & 0.007 \\
\hline b.Tidak Berisiko & 6 & 7.4 & 75 & 92.6 & 81 & 100.0 & \\
\hline \multicolumn{8}{|l|}{ Status Gizi } \\
\hline a. Gizi Tidak Baik & 5 & 41.7 & 7 & 58.3 & 12 & 100.0 & 0.004 \\
\hline b. Gizi Baik & 6 & 7.3 & 76 & 92.7 & 82 & 100.0 & \\
\hline \multicolumn{8}{|l|}{ Status Ekonomi } \\
\hline a. Rendah & 7 & 14.9 & 40 & 85.1 & 47 & 100.0 & 0.521 \\
\hline b. Tinggi & 4 & 8.5 & 43 & 91.5 & 47 & 100.0 & \\
\hline \multicolumn{8}{|l|}{$\begin{array}{l}\text { Penyakit/komplikasi } \\
\text { selama kehamilan }\end{array}$} \\
\hline a. Ada & 11 & 52.4 & 10 & 47.6 & 21 & 100.0 & 0.000 \\
\hline b. Tidak & 0 & 0.0 & 73 & 100.0 & 73 & 100.0 & \\
\hline
\end{tabular}


Berdasarkan Tabel 1 dapat disimpulkan bahwa, dari 81 responden, ibu yang umurnya tidak berisiko saat hamil $92.6 \%$ bayi lahir dengan berat badan nomal, sedangkan dari 13 responden dengan ibu hamil pada umur berisiko sebanyak $61.5 \%$ bayi lahir dengan berat badan nomal. Hasil uji statistik didapatkan nilai $\mathrm{p}=0.007$, yang berarti ada hubungan umur ibu saat hamil dengan kejadian berat badan lahir rendah di Wilayah Kerja UPTD Puskesmas Panga Tahun 2017.

Pada variabel status gizi ibu dapat dilihat bahwa 82 responden, ibu dengan status gizi baik saat hamil $92.7 \%$ bayi lahir dengan berat badan normal, sedangkan dari 12 responden, ibu dengan status gizi tidak baik $58.3 \%$ bayi lahir dengan berat badan normal. Hasil uji statistik didapat nilai $\mathrm{p}=0.004$, artinya ada hubungan status gizi ibu saat hamil dengan kejadian berat badan lahir rendah di Wilayah Kerja UPTD Puskesmas Panga Tahun 2017.

Pada variabel status ekonomi dapat dilihat bahwa dari 47 responden, ibu dengan status ekonomi tinggi $91.5 \%$ bayi lahir dengan berat badan normal, sedangkan dari 47 responden, ibu dengan status ekonominya rendah $85.1 \%$ bayi lahir dengan berat badan normal. Hasil uji statistik didapat nilai $\mathrm{p}=0.521$, artinya tidak ada hubungan status ekonomi dengan kejadian berat badan lahir rendah di Wilayah Kerja UPTD Puskesmas Panga Tahun 2017.

Pada variabel penyakit/komplikasi selama kehamilan dapat dilihat bahwa dari 73 responden, ibu yang tidak memiliki penyakit selama kehamilan $100 \%$ bayi lahir dengan berat badan normal, sedangkan dari 21 responden, ibu yang memiliki penyakit selama kehamilan $47.6 \%$ bayi lahir dengan berat badan normal. Hasil uji statistik didapat nilai $\mathrm{p}=0.000$, artinya ada hubungan penyakit/komplikasi selama kehamilan dengan kejadian berat badan lahir rendah di Wilayah Kerja UPTD Puskesmas Panga Tahun 2017.

\section{Pembahasan}

1. Analisis Hubungan Umur Ibu dengan Kejadian Berat Badan Lahir Rendah

Hasil penelitian menunjukkan bahwa ada hubungan umur ibu saat hamil dengan kejadian berat badan lahir rendah di Wilayah Kerja UPTD Puskesmas Panga Tahun 2017, dengan nilai $\mathrm{p}=0.007$, dan $\mathrm{OR}=7.813$, yang berarti ibu dengan umur berisiko saat hamil memiliki peluang 7.813 kali lebih besar melahirkan bayi dengan berat badan lahir rendah dibandingkan dengan ibu hamil pada umur tidak berisiko.

Hasil penelitian ini sejalan dengan penelitian yang dilakukan oleh Hasanah, Kurniawati dan Kurniati (2011) di Ruang BBRT RSUP Dr.Kariadi Semarang dengan jenis 
penelitian korelasi dan jumlah sampel 46 responden yang diambil dengan nilai $\mathrm{p}=0.000$, yang berarti ada hubungan umur ibu dengan kejadian berat badan lahir rendah. Hasil penelitian Lusiana dan Megasari (2014) di RSUD Arifin Achmad Prov Riau tahun 20132014, dengan studi kasus kontrol, didapatkan hasil bahwa ibu yang termasuk kategori umur beresiko (umur $<2$ tahun dan umur $>35$ tahun) lebih berisiko melahirkan bayi dengan BBLR 5 kali lebih besar dibandingkan dengan ibu yang tidak termasuk kategori umur tidak berisiko.

Ibu hamil pada umur terlalu muda ( $<20$ tahun) tidak atau belum siap untuk memperlihatkan lingkungan yang diperlukan untuk pertumbuhan janin. Pada umur terlalu muda akan terjadi kompetisi makanan antar janin dan ibunya sendiri yang masih dalam pertumbuhan dan adanya pertumbuhan hormonal yang terjadi selama kehamilan, sedangkan ibu hamil di atas 35 tahun lebih karena pengaruh turunnya cadangan zat besi dalam tubuh akibat masa fertilisasi (Rukiyah dan Yulianti,2011).

Peneliti berasumsi bahwa umur seorang wanita saat hamil mementukan kesehatan diri dan anaknya kelak, umur yang terlalu muda berisiko untuk hamil yang disebabkan oleh belum matangnya organ reproduksi, sedangkan umur terlalu tua berisiko untuk hamil dikarenakan sudah mulai berkurangnya hormon dalam tubuh. Pada penelitian ini ditemukan umur ibu yang berisiko ( $<20$ tahun dan $>35$ tahun) melahirkan bayi dengan berat badan lahir rendah sebanyak 5 orang, namun ada pula ibu dengan umur tidak berisiko melahirkan anak dengan berat badan lahir rendah sebanyak 6 orang. hal ini dapat disebabkan oleh ibu yang umur berisiko sudah mengetahui komplikasi yang dapat terjadi pada diri dan janinnya, sehingga mereka rutin melakukan pemeriksaan kehamilan disertai dengan peningkatan status gizi. Lain halnya dengan ibu yang umur tidak berisiko juga bisa saja melahirkan bagi dengan berat badan lahir rendah, hal ini dapat disebabkan karena status gizi ibu yang tidak baik, penghasilan yang tidak memadai sehingga tidak dapat memenuhi kebutuhan sehari-hari dan ada pula yang mengalami penyakit selama kehamilan, seperti anemia dan pre eklampsia.

\section{Hubungan Status Gizi dengan Kejadian Berat Badan Lahir Rendah}

Hasil penelitian menunjukkan bahwa ada hubungan status gizi ibu saat hami dengan kejadian berat badan lahir rendah di Wilayah Kerja UPTD Puskesmas Panga tahun 2017, dengan nilai $\mathrm{p}=0.004$ dan $\mathrm{OR}=9.048$, yang artinya ibu dengan status gizi tidak baik saat 
hamil berisiko 9 kali lebih besar melahirkan bayi dengan berat badan lahir rendah, dibandingkan dengan ibu dengan status gizi baik saaat hamil.

Hasil penelitian ini sejalan dengan penelitian yang dilakukan oleh Nurfitria (2015), di Wilayah Kerja Puskesmas Sukorejo Ponorogo, dengan desain penelitian cross sectional dan jumlah sampel 82 orang, didapat nilai $\mathrm{p}=0.048$, yang berarti ada hubungan status gizi dengan kejadian berat badan lahir rendah.

Pengaruh gizi terhadap kehamilan sangat penting, pada wanita hamil dengan mal nutrisi menyebabkan volume darah menjadi berkurang, aliran darah ke uterus dan plasenta berkurang, ukuran plasenta berkurang dan transfer nutrient melalui plasenta berkurang sehingga janin tumbuh lambat atau terganggu. Ibu hamil dengan kekurangan gizi cenderung melahirkan premature atau BBLR (Romaulim, 2011).

Peneliti berasumsi bahwa status gizi ibu selama hamil menentukan pertumbuhan dan perkembangan janin, hal ini dikarenakan saat hamil tubuh membutuhkan zat gizi yang penting untuk dapat disalurkan ke janin melalui plasenta, apabila ibu tidak mengonsumsi makanan dengan gizi yang baik, maka akan berpengaruh terhadap pertumbuhan dan perkembangan anaknya kelak, termasuk dapat melahirkan bayi dengan berat badan rendah. Hasil penelitian juga memperlihatkan bahwa 6 orang ibu dengan status gizi baik, namun melahirkan bayi dengan berat lahir rendah, hal ini dapat dipengaruhi oleh usia saat hamil, status ekonomi serta penyakit yang dialami selama kehamilan.

\section{Hubungan Status Ekonomi dengan Kejadian Berat Badan Lahir Rendah}

Hasil penelitian menunjukkan bahwa dari 47 responden, ibu dengan status ekonomi tinggi $91.5 \%$ bayi lahir dengan berat badan normal, sedangkan dari 47 responden, ibu dengan status ekonominya rendah $85.1 \%$ bayi lahir dengan berat badan normal. Hasil uji statistik didapat nilai $\mathrm{p}=0.521$, artinya tidak ada hubungan status ekonomi dengan kejadian berat badan lahir rendah di Wilayah Kerja UPTD Puskesmas Panga Tahun 2017.

Hal ini berbeda dengan teori yang disampaikan oleh Proverawati dan Asfuah (2009), ekonomi seseorang mempengaruhi dalam pemilihan makanan yang akan dikonsumsi sehari-hari, seseorang dengan ekonomi yang tinggi kemungkinan besar gizi yang dibutuhkan tercukupi ditambah lagi adanya pemeriksaan membuat gizi ibu semakin terpantau. Ibu hamil dengan kekurangan zat gizi yang penting bagi tubuh akan menyebabkan anak lahir dengan berat badan rendah. 
Peneliti berasumsi bahwa status ekonomi tidak menjadi faktor utama terjadinya kelahiran bayi dengan berat badan lahir rendah, hal ini dapat disebabkan oleh seseorang dengan penghasilan rendah juga mampu memenuhi kebutuhan sehari-harinya, karena makanan bergizi tidak berarti makanan tersebut harus mahal, di wilayah kerja UPTD Puskesmas Panga memiliki perkebunan yang luas, ini menjadi hal utama tidak dibutuhkan biaya yang banyak untuk memenuhi kebutuhan seperti sayur-sayuran.

4. Hubungan Penyakit/Komplikasi Selama Kehamilan dengan Kejadian Berat Badan Lahir Rendah

Hasil penelitian ini menunjukkan bahwa ada hubungan yang signifikan penyakit/komplikasi selama kehamilan dengan kejadian berat badan lahir rendah di Wilayah Kerja UPTD Puskesmas Panga Tahun 2017, dengan nilai p=0.000. Dari 11 orang bayi dengan berat badan lahir rendah, seluruhnya adalah dengan ibu yang memiliki penyakit selama kehamilan.

Hasil penelitian ini sejalan dengan penelitian yang dilakukan oleh Lusiana dan Megasari (2014) di RSUD Arifin Achmad Prov Riau tahun 2013-2014, dengan studi kasus kontrol, didapat nilai $\mathrm{p}=0.001$ dan $\mathrm{OR}=3.986$, yang berarti ibu yang memiliki penyakit selama kehamilan memiliki risiko 3.9 kali lebih besar melahirkan bayi dengan berat badan lahir rendah. Hasil penelitian yang dilakukan oleh Suryati (2013) dengan hasil ada hubuungan anemia $(\mathrm{p}=0.000)$ dan KEK $(\mathrm{p}=0.000)$ dengan kejadian Berat Badan Lahir Rendah di Wilayah Kerja Puskesmas Air Dingin Tahun 2013.

Beberapa komplikasi langsung dari kehamilan seperti anemia, perdarahan, preeclampsia/eklampsi, hipertensi, ketuban pecah dini (KPD) dan kelainan lainnya, keadaan tersebut mengganggu kesehatan ibu dan juga pertumbuhan janin dalam kandungan sehingga meningkatkan risiko kelahiran bayi dengan berat rendah (Prawirohardjo, 2008 ; Manuaba, 2010).

Peneliti berasumsi bahwa penyakit atau komplikasi selama kehamilan berpengaruh dengan kelahiran bayi kelak, hal ini disebabkan karena saat ibu hamil yang mengalami gangguan, maka akan berpengaruh kepada pertumbuhan dan perkembangan janinnya. Ibuibu yang berada di wilayah kerja UPTD Puskesmas Pangan, sebagian besar mengalami anemia dan kekurangan energi kronik saat hamil, sudah berbagai upaya yang dilakukan petugas puskesmas untuk menurunkan angka kejadian ini, namun angka kejadian anemia 
dan KEK tetap meningkat setiap tahunnya. Hal ini disebabkan karena luasnya wilayah dan jarak ke desa yang terlampau jauh, sehingga menjadi salah satu penghambat bagi petugas kesehatan dan masyarakatpun sulit untuk menjangkau tempat pelayanan kesehatan, sehingga masih ada ibu hamil yang tidak rutin mengontrol kehamilannya dan tidak mengetahui kondisi kesehatan ibu dan janin.

\section{KESIMPULAN}

Berdasarkan hasil penelitian dapat disimpulkan bahwa ada hubungan umur ibu ( $p$ value $=0.007)$, status gizi saat hamil $(p$ value $=0.004)$ dan penyakit komplikasi selama kehamilan $(p$ value $=0.000)$ dengan kejadian berat badan lahir rendah di Wilayah Kerja UPTD Puskesmas Panga Tahun 2017, sedangkan status ekonomi ( $p$ value $=0.521$ ) tidak berhubungan dengan kejadian berat badan lahir rendah di Wilayah Kerja UPTD Puskesmas Panga Tahun 2017.

\section{SARAN}

Diharapkan agar petugas kesehatan baik dari Puskesmas Panga maupun Dinas Kesehatan terkait lebih gencar lagi dalam memberikan pelayanan kesehatan dalam bentuk penyuluhan kesehatan yang dapat dilakukan secara rutin dan dapat pula disertai dengan pembagian brosur, pemasangan spanduk atau baliho khususnya tentang kesehatan ibu dan anak.

\section{UCAPAN TERIMA KASIH}

Ucapan terima kasih kepada Universitas Ubudiyah Indonesia yang telah memberikan dukungan finansial dalam penelitian ini dan ucapan terima kasih kepada Kepala UPTD Puskesmas Panga yang telah memberikan izin penelitian.

\section{DAFTAR PUSTAKA}

Hasanah, Kurniawati dan Kurniati. (2011). Faktor-faktor yang Berhubungan dengan Kejadian Bayi Berat Lahir Rendah (BBLR) di Ruang BBRT RSUP Dr. Kariadi Semarang.

Kemenkes. (2015). Profil Kesehatan Indonesia Tahun 2015. Kementrian Kesehatan Republik Indonesia.

Lusiana dan Megasari. (2014). Faktor-faktor yang Berhubungan dengan Kejadian BBLR. Jurnal Ilmu Kebidanan, Volume II, Nomor 3, Desember 2014. 
Manuaba. (2007). Ilmu Kebidanan Penyakit Kandungan dan KB. Jakarta : EGC

Manuaba. (2010). Ilmu Kebidanan Penyakit Kandungan dan KB. Jakarta : EGC

Nurfitria. (2015). Faktor-faktor yang Berkaitan dengan Kejadian Berat Badan Lahir Rendah di Wilayah Kerja Puskesmas Sukorejo Ponorogo. repository.ipb.ac.id/jspui/bitstream/123456789/87044/1/I16unn.pdf

Prawirohardjo, S. (2008). Ilmu Kebidanan. Jakarta : Yayasan Bina Pustaka-Sarwono Prawirohardjo.

Proverawati dan Asfuah. (2009). Gizi Untuk Perempuan. Yogyakarta : Mulia Medika

Reflita dan Mastian. (2010). Faktor-faktor yang Berhubungan dengan Kejadian Berat Badan Lahir Rendah di RS Dr. M Djamil Padang. Ners Jurnal Keperawatan, Volume 7, No.2 Desember $2011: 114-120$.

Riset Kesehatan Dasar. (2007). Riskesdas 2007. Badan Penelitian dan Pengembanganan Kesehatan. Kementrian Kesehatan RI:2007.

Rukiyah, dan Yulianti. (2010). Asuhan Kebidanan IV (Patologi Kebidanan). Jakarta : Trans Info Media.

Romauli, S. (2011). Buku Ajar Kebidanan Konsep Dasar Asuhan Kehamilan. Yogyakarta : Nuha Medika

Suryati. (2013). Faktor-faktor yang Mempengaruhi Kejadian BBLR di Wilayah Kerja Puskesmas Air Dingin Tahun 2013. Jurnal Kesehatan Masyarakat Andalas, p-ISSN 19783833

Dinas Kesehatan Provinsi Aceh. (2015). Profil Kesehatan Aceh 2015. http://dinkes.acehprov.go.id 